\title{
The research of ammonium 2-((4-amino-5-(morpholinomethyl)- 4H-1,2,4-triazole-3-yl)thio)acetate (PKR-177) influence on biochemical indices in rats blood under hepatitis initiated by tetrachloride methane
}

\author{
R. O. Shcherbyna ${ }^{1}$, T. O. Samura ${ }^{1}$, B. P. Kyrychko², T. V. Zvenihorodska ${ }^{2}$, I. V. Hyrenko ${ }^{2}$ \\ ${ }^{1}$ Zaporizhzhia State Medical University, Ukraine, ${ }^{2}$ Poltava State Agrarian Academy, Ukraine
}

Hepatitis is a disease which causes liver inflammation. The most widespread hepatitis pathogens are hepatitis viruses but it can also be caused by other infections such as some toxic substances and auto-immune diseases.

The aim of research. The research of the influence of ammonium 2-((4-amino-5-(morpholinomethyl)-4H-1,2,4-triazole-yl-3) thio)acetate (PKR-177) on biochemical indices of rats blood under hepatitis caused by tetrachloride methane.

The materials and methods of research. $1 \%$ aqueous solution of PKR-177 substance was used as the material of this research. The studying was held according to methodological recommendations of "Preclinical research of medical substances". Experimental animals were clinically observed. Evaluation of biochemical and functional indices of their organisms (incl. liver) was carried out 24 hours after the last injection of tetrachloride methane.

Results and their discussion. Clinical analysis demonstrated that hypodermic injection of oil solution of tetrachloride methane resulted in abrupt deterioration of the overall health condition of experimental animals. They were not keen to move, gathered together in groups, partially refused to eat. Entire refusal from food was observed after repeated injection of tetrachloride methane. Animals injected with PKR-177 and Thioprotectin intensively consumed water, ate food in small portions. After 24 hours blood tests of all animals under research were made for profound biochemical studying. As a result of the reproduction of acute toxic lesions (in comparison with intact animals) a violation of the functional capacity of the liver was noted. In the serum this was manifested by a sharp decline in activity of transaminases (ALT and AST). This occurred on a background of increased activity of lactate dehydrogenase and gamma glutamyl transpeptidase. The injection of carbon tetrachloride produced tendency to decrease the content of albumin, total protein, albumin/globulin ratio, glucose level, cholesterol, triacylglycerides, total bilirubin and $\alpha$-amylase activity.

Conclusions. The influence of ammonium 2-((4-amino-5-(morfolinomethyl)-4H-1,2,4-triazole-3-yl)thio)acetate (PKR-177) on blood biochemical parameters in rats with hepatitis caused by tetrachlormethan was studied. 27 biochemical and functional parameters of the blood of experimental animals were investigated. In the result of experiment it was found that the activity of ALT, AST enzymes was higher in animals injected by the PKR-177 solution compared to rats from the first and fourth experimental groups.

\section{Аослідження впливу амонію 2-((4-аміно-5-(морфолінометил)-4H-1,2,4-тріазол-3-іл)тіо) ацетату (ПКР-177) на біохімічні показники крові в щурів при тетрахлорметановому гепатиті}

\section{Р. О. Щербина, Т. О. Самура, Б. П. Киричко, Т. В. Звенігородська, І. В. Гиренко}

Гепатит - захворювання, що призводить до запалення печінки. Найпоширенішими збудниками гепатиту у світі $є$ віруси гепатиту, але це захворювання може бути викликане іншими інфекціями, деякими токсичними речовинами та аутоімунними захворюваннями.

Мета роботи - дослідження впливу амонію 2-((4-аміно-5-(морфолінометил)-4Н-1,2,4-тріазол-3-іл)тіо)ацетату (ПКР-177) на біохімічні показники крові в щурів при тетрахлорметановому гепатиті.

Матеріали та методи. Матеріалом для дослідження був 1 \% водний розчин субстанції ПКР-177. Дослід здійснили, керуючись методичними рекомендаціями «Доклінічні дослідження лікарських засобів». За експериментальними тваринами встановлювали клінічний нагляд. Вивчення біохімічних і функціональних показників організму (в тому числі печінки) проводили через 24 години після останнього введення тетрахлорметану.

Результати. Клінічними спостереженнями встановлено, що підшкірне введення олійного розчину тетрахлорметану призводило до різкого погіршення загального стану експериментальних тварин. Після повторного введення тетрахлорметану спостерігали повну відмову від корму. Тварини, яким ін'єктували ПКР-177 і тіопротектин, посилено споживали воду, корм поїдали в невеликій кількості. Через 24 години в усіх піддослідних тварин проводили відбір зразків крові для розширеного біохімічного дослідження. У результаті відтворення гострого токсичного ураження відзначено (порівняно з інтактними тваринами) порушення функціональної здатності печінки. У сироватці крові це проявлялося різким зниженням активності трансаміназ (АлАт та АсАт). Це відбувалось на тлі підвищення активності лактатдегідрогенази та гама-глутамілтранспептидази. Введення тетрахлорметану створювало тенденцію до зниження вмісту альбуміну, загального білка, альбумін-глобулінового коефріцієнта, рівня глюкози, холестеролу, триацилгліцеридів, загального білірубіну та активності $\alpha$-амілази.

Висновки. Дослідили вплив ПКР-177 на біохімічні показники крові в щурів при тетрахлорметановому гепатиті. Досліджено 27 біохімічних і функціональних показників крові піддослідних тварин. У результаті експерименту встановлено, що активність ферментів АлАт, АсАт вища у тварин, яким вводили розчин ПКР-177, порівняно із щурами першої та четвертої дослідних груп.
Key words: 1,2,4-triazole, biochemical indicators, hepatitis.

Zaporozhye medical journal 2017; $19(6), 819-822$ DOI: 10.14739/2310-1210 2017.6.115304

E-mail: rscherbyna@gmail.com

Кнючові слова: 1,2,4-тріазол, біохімічні показники, гепатит.

Запорізький медичний журнал. - 2017. T. 19, № 6(105). C. 819-822 


\section{Ключевые слова: \\ 1,2,4-триазол, \\ биохимические \\ показатели, \\ Исследование влияния аммония 2-((4-амино-5-(морфолинометия)- 4Н-1,2,4-триазол-3-ил)тио)ацетата (ПКР-177) на биохимические показатели крови у крыс при тетрахлорметановом гепатите}

гепатит.

Запорожский

медицинский

журнал. - 2017. -

T. 19, № 6(105). -

C. 819-822

\author{
Р. А. Щербина, Т. А. Самура, Б. П. Киричко, Т. В. Звенигородская, И. В. Гиренко
}

Гепатит - это заболевание, которое ведет к воспалению печени. Наиболее распространенными возбудителями гепатита в мире являются вирусы гепатита, но данное заболевание может быть вызвано и другими инфекциями, некоторыми токсичными веществами и аутоиммунными заболеваниями.

Цель работы - исследование влияния аммония 2-((4-амино-5 (морфолинометил)-4Н-1,2,4-триазол-3-ил)тио)ацетата (ПКР-177) на биохимические показатели крови у крыс при тетрахлорметановом гепатите.

Материалы и методы. Материалом для исследования был 1 \% водный раствор субстанции ПКР-177. Опыт проводили, руководствуясь методическими рекомендациями «Доклинические исследования лекарственных средств». Над экспериментальными животными устанавливали клиническое наблюдение. Изучение биохимических и функциональных показателей организма (в том числе печени) проводили через 24 часа после последнего введения тетрахлорметана.

Результаты. Клиническими наблюдениями установлено, что подкожное введение масляного раствора тетрахлорметана приводило к резкому ухудшению общего состояния экспериментальных животных. После повторного введения тетрахлорметана наблюдали полный отказ от корма. Животные, которым вводили ПКР-177 и тиопротектин, усиленно потребляли воду, корм поедали в небольшом количестве. Через 24 часа у всех подопытных животных проводили отбор образцов крови для расширенного биохимического исследования. В результате воспроизведения острого токсического поражения отмечено (по сравнению с интактными животными) нарушение фуннциональной способности печени. В сыворотке крови это проявлялось резким снижением активности трансаминаз (АлАТ и АсАТ). Это происходило на фоне повышения активности лактатдегидрогеназы и гамма-глутамилтранспептидазы. Введение тетрахлорметана создавало тенденцию к снижению содержимого альбумина, общего белка, альбумин-глобулинового коэфффициента, уровня глюкозы, холестерина, триацилглицеридов, общего билирубина и активности а-амилазы.

Выводы. Проведено исследование влияния ПКР-177 на биохимические показатели крови у крыс при тетрахлорметановом гепатите. Исследовано 27 биохимических и функциональных показателей крови подопытных животных. В результате эксперимента установлено, что активность ферментов АлАТ, АсАТ выше у животных, которым вводили раствор ПКР177 по сравнению с крысами первой и четвертой исследовательских групп.,

\section{Introduction}

Hepatitis is a disease caused by liver inflammation [1]. This pathology can be self-curable or can cause liver fibrosis, cirrhosis or cancer. The most wide-spread hepatitis pathogens are hepatitis viruses but it can also be caused by other infections, some toxic substances (alcohol, drugs, and halogenated hydrocarbons) as well as auto-immune diseases can also cause hepatitis [1].

Elaboration of new means which defense and regenerate liver can take place in two possible ways: growing new synthetic molecules and using medicinal plant material [2]. Scientists-synthetics have already concentrated their attention on the class of nitrogen-containing heterocycles [3-5]. In this context the most interesting compounds are thio derivatives of 1,2,4-triazole [6]. Derivatives of this heterocyclic system are actively used in medical practice as antiviral, antioxidant, hepatoprotective, immunostimulating remedies [3]. Thus, well-known hepatoprotective medicine "Thiotriazoline" [7] from the point of view of its chemical composition is a derivative of 1,2,4-triazole-5-thioacetate acid. Therefore the research of the influence of ammonium

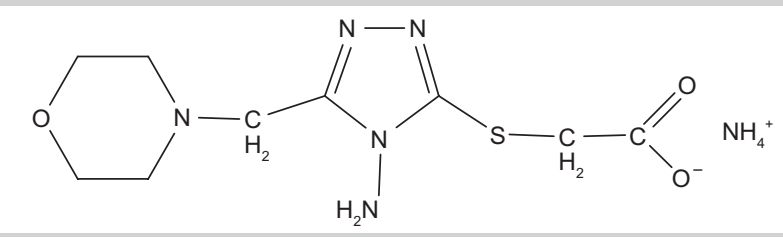

Fig. 1. Structural formula of ammonium 2-((4-amino-5-(morpholinomethyl)-4H-1,2,4-triazole-yl-3) thio)acetate (PKR-177).
2-((4-amino-5-(morpholinomethyl)-4H-1,2,4-triazole-yl-3) thio)acetate (PKR-177) on biochemical indices in rats blood under tetrachloride methane hepatitis is topical as far as the obtained results can be useful in the course of original substances formation with hepatoprotective properties.

\section{The aim of research}

The research of the influence of ammonium 2-((4-amino5-(morpholinomethyl)-4H-1,2,4-triazole-yl-3)thio)acetate (PKR-177) on biochemical indices of rats blood under hepatitis initiated by tetrachloride methane.

\section{Materials and methods}

As an object of research ammonium 2-((4-amino-5-(morpholinomethyl)-4H-1,2,4-triazole-yl-3)thio)acetate (PKR-177, Fig. 1) was used. It has been synthesized at the department of toxicological and inorganic chemistry of Zaporizhzhia State Medical University [8].

The investigation of biochemical indices was carried out on the basis of scientific research laboratory at the department of surgery and obstetrics of Poltava State Agricultural Academy and central biochemical laboratory of the 4th city clinical hospital of Poltava.

As the material of this research $1 \%$ aqueous solution of PKR-177 substance was used. The investigation was held according to methodological recommendations of "Preclinical research of medical substances" edited by the corresponding member of the Academy of Medical Science of Ukraine O. V. Stefanov [9]. 
For experimental part of the research laboratory animals were used - white rats (male) weighing 130-150 g, which formed four investigation groups. There was modeling of liver acute inflammation in the animals of the first group under hypodermic injection of $50 \%$ oil solution of tetrachloride methane (TCM) taken in the proportion of $0.8 \mathrm{ml}$ to $100 \mathrm{~g}$ of weight during 2 days. The animals of the second group of research were intact (INT). The rats of the third research group an hour before injection of $50 \%$ oil solution of tetrachloride methane were intramuscularly injected with $1 \%$ aqueous solution of the compound PKR-177 in the proportion of $2.0-2.5 \mathrm{mg}$ per animal. In two hours after the injection of tetrachloride methane the solution of the PKR-177 substance was given again. The next day all the manipulations were repeated. The animals of the fourth group were also triggered by the injection of $50 \%$ oil solution of tetrachloride methane, though, instead of PKR-177 compound the comparison substance was applied - Thioprotectin (TIO) (2.0-2.5 mg per animal). The same manipulations were repeated the next 24 hours.

Experimental animals were clinically observed. Studying of biochemical and functional indices of their organism (incl. liver) was carried out 24 hours after the last injection of tetrachloride methane.

\section{Results and their discussion}

Clinical studying demonstrated that hypodermic injection of oil solution of tetrachloride methane resulted in abrupt deterioration of the overall health condition of experimental animals. They were not keen to move, gathered together in groups, partially refused from food. After repeated injection of tetrachloride methane entire refusal from food was observed. Animals injected with PKR-177 and Thioprotectin intensively consumed water, ate food in small portions. After 24 hours blood tests of all research animals were made for profound biochemical examination. The results of biochemical tests of blood serum are shown in Table 1.

As a result of the reproduction of acute toxic lesion (in comparison with intact animals) a violation of the functional capacity of the liver was noted. In the serum, this was manifested by a sharp decline in activity of transaminases (ALT and AST). This occurred on a background of increased activity of lactate dehydrogenase and gamma glutamyl transpeptidase (Table 1). Important is the fact that the introduction of carbon tetrachloride produced tendency to decrease the content of albumin, total protein, albumin/globulin ratio, glucose level, cholesterol, triacylglycerides, total bilirubin and a-amylase activity. Also 24 hours after the last injection with carbon tetrachloride, the animals which were administered compound PKR-177 and Tioprotectin stayed alive, partly preserved appetite, noted the increased thirst. Transaminase activity of enzymes (ALT, AST) was higher in animals which were injected with solution of PKR-177 compared with rats of the first and fourth experimental groups. In animals injected with PKR-177 and Tioprotectin against the invasion of carbon tetrachloride, the increased level of uric acid was noted.

\section{Conclusions}

1. The influence of ammonium 2-((4-amino-5-(morfolinomethyl)-4H-1,2,4-triazole-3-yl)thio)acetate (PKR-177) on

Table 1. Biochemical indices of blood serum of the research rats

\begin{tabular}{|c|c|c|c|c|c|c|}
\hline № & Indices & Reference norm & $\begin{array}{l}\text { The } 1^{\text {st }} \text { research group } \\
\text { (TCM) }\end{array}$ & $\begin{array}{l}\text { The } 2^{\text {nd }} \text { research group } \\
\text { (INT) }\end{array}$ & $\begin{array}{l}\text { The } 3^{\text {rd }} \text { research group } \\
\text { (TCM. PKR-177) }\end{array}$ & $\begin{array}{l}\text { The } 4^{\text {th }} \text { research group } \\
\text { (TCM, TIO) }\end{array}$ \\
\hline 1 & Albumin, $g / l$ & $32-52$ & $30.2 \pm 1.93$ & $34.6 \pm 0.43$ & $30.2 \pm 1.50$ & $32.0 \pm 1.07$ \\
\hline 2 & Total protein, g/l & $65-85$ & $69.6 \pm 2.36$ & $76.6 \pm 1.28$ & $68.0 \pm 2.36$ & $72.0 \pm 2.79$ \\
\hline 3 & Alcaline phosphatase, IU/I & $64-600$ & $1107 \pm 157.29$ & $1157 \pm 136.05$ & $1052 \pm 278.53$ & $948 \pm 116.52$ \\
\hline 4 & ALT (alanine aminotransferase), IU/I & $5-40$ & $45.2 \pm 12.01$ & $175.0 \pm 21.67$ & $78.4 \pm 20.17$ & $52.4 \pm 19.31$ \\
\hline 5 & AST (aspartate aminotransferase), IU/I & $5-35$ & $41.2 \pm 19.52$ & $231.6 \pm 14.81$ & $217.4 \pm 43.34$ & $181.0 \pm 57.72$ \\
\hline 6 & LDG (lactate dehydrogenase), IU/I & $114-450$ & $4550.2 \pm 1113.3$ & $2615.6 \pm 507.9$ & $4599.8 \pm 1133.9$ & $5179.6 \pm 613.3$ \\
\hline 7 & GGTP (gamma glutamyl transpeptidase), IU/I & $5-30$ & $4.8 \pm 0.43$ & $2.2 \pm 0.43$ & $4.6 \pm 1.07$ & $4.4 \pm 1.07$ \\
\hline 8 & Creatinine, $\mathrm{mcmol} / \mathrm{l}$ & $44-107$ & $58.8 \pm 9.01$ & $56.8 \pm 2.57$ & $58.4 \pm 9.44$ & $55.0 \pm 3.00$ \\
\hline 9 & Urea, mmol/l & $2.5-8.3$ & $6.34 \pm 0.87$ & $5.70 \pm 0.36$ & $6.32 \pm 1.18$ & $6.36 \pm 0.68$ \\
\hline 10 & Glucose, $\mathrm{mmol} / \mathrm{l}$ & $3.5-6.3$ & $7.2 \pm 0.43$ & $10.0 \pm 0.27$ & $5.9 \pm 1.05$ & $7.0 \pm 0.53$ \\
\hline 11 & Cholesterol, mmol/l & $3.6-6.5$ & $0.86 \pm 0.09$ & $1.35 \pm 0.15$ & $1.11 \pm 0.16$ & $0.96 \pm 0.03$ \\
\hline 12 & Triglycerides, mmol// & $0.45-2.0$ & $0.36 \pm 0.07$ & $1.28 \pm 0.17$ & $0.47 \pm 0.06$ & $0.53 \pm 0.05$ \\
\hline 13 & alpha-amilase IU/I & $10-220$ & $990.4 \pm 188.8$ & $1395.4 \pm 69.3$ & $850.4 \pm 126.6$ & $1159.6 \pm 236.0$ \\
\hline 15 & Conjugated bilirubin & $25 \%$ from general & $3.0 \pm 0.43$ & $3.4 \pm 0.21$ & $3.8 \pm 0.21$ & $3.8 \pm 0.21$ \\
\hline 16 & Indirect bilirubin & & $7.4 \pm 1.28$ & $8.6 \pm 0.64$ & $10.2 \pm 1.07$ & $10.2 \pm 0.86$ \\
\hline 17 & Thymol test, units & to 4 units & $1.74 \pm 0.17$ & $2.12 \pm 0.27$ & $1.82 \pm 0.12$ & $1.80 \pm 0.13$ \\
\hline 18 & Uric acid, mcmol/l & $140-340$ & $101.6 \pm 15.23$ & $113.4 \pm 28.32$ & $156.6 \pm 28.96$ & $174.8 \pm 14.59$ \\
\hline 19 & Inorganic phosphorus, mmol/l & $0.8-1.5$ & $2.12 \pm 0.12$ & $2.50 \pm 0.14$ & $2.19 \pm 0.16$ & $2.45 \pm 0.12$ \\
\hline 20 & Calcium, mmol/l & $2.22-2.75$ & $2.44 \pm 0.06$ & $2.50 \pm 0.05$ & $2.40 \pm 0.03$ & $2.36 \pm 0.08$ \\
\hline 21 & C-reactive protein & Negative & Negative & Negative & Negative & Negative \\
\hline 22 & Titter anti-streptolysin-O, units & $<250$ units & $<250$ & $<250$ & $<250$ & $<250$ \\
\hline 23 & Seromucoid, units & $<0.200$ items & $0.128 \pm 0.008$ & $0.128 \pm 0.008$ & $0.130 \pm 0.008$ & $0.124 \pm 0.006$ \\
\hline 24 & Rheumatoid factor & Negative & Negative & Negative & Negative & Negative \\
\hline 25 & Albumins, $\%$ & $53.0-66.0$ & $43.4 \pm 2.23$ & $45.18 \pm 0.45$ & $44.38 \pm 0.98$ & $44.46 \pm 0.30$ \\
\hline 26 & Globulins, \% & $34.0-47.0$ & $56.6 \pm 2.23$ & $54.8 \pm 0.47$ & $55.6 \pm 0.98$ & $55.5 \pm 0.32$ \\
\hline 27 & Coefficient Alb./Glob & $1.2-2.0$ & $0.78 \pm 0.07$ & $0.83 \pm 0.015$ & $0.80 \pm 0.03$ & $0.80 \pm 0.01$ \\
\hline
\end{tabular}


blood biochemical parameters in rats with tetrachlormethan hepatitis was studied. So we have investigated 27 biochemical and functional parameters of the experimental animal's blood.

2. In the result of the study it was found that the activity of enzymes ALT, AST was higher in animals injected with solution PKR-177 compared with rats of the first and fourth experimental groups.

Prospects for further research are in more depth study of ammonium 2-((4-amino-5-(morfolinomethyl)-4H-1,2,4-triazole-3-yl)thio)acetate on the ability of display hepatoprotective effect on various models of hepatitis.

Funding. The research was carried out within the state budget scientific-research work "Synthesis of new biologically active substances - derivatives of 5-(alkyl-, aryl-, heteryl-) of 4-R-(amino)-1,2,4-triazoly-3-thiones for the creation of original drugs with analgesic, actoprotective, antimicrobial, anti-inflammatory and diuretic effect" (0115U003470), 2015-2017, funded by the Ministry of Health of Ukraine.

Фінансування. АосліАження виконано в рамках держбюАжетної НАР "Синтез нових біологічно активних речовин похідних 5-(алкіл-, арил-, гетерил-) похіАних 4-R-(аміно)1,2,4-тріазоліл-3-тіонів Аля створення оригінальних мікарських засобів з аналгетичною, актопротекторною, антимікробною, Аіуретичною та протизапальною Аією", (0115U003470) 2015-2017, що фінансується М03 України.

\section{References}

[1] (2014) Vsemirnaya organizaciya zdravoohraneniya [World Health Organization]. Retrieved from http://www.who.int/features/qa/76/ru/ [in Russian].

[2] Kulmagambetov, I. R., Datkhayev, U. M., Sakipova, Z. B., Makhatova, B. G., \& Omirbayeva, A. Y. (2013). Sozdaniye novykh lekarstvennykh sredstv iz rastitel'nogo syrya obladayushchikh gepatoprotektorno aktivnost'yu [Creation of new pharmaceuticals from the vegetable raw materials, possessing hepatoprotective activity]. Vestnik KazNMU, 5(3), 125-127. [in Russian].

[3] Parchenko, V. V. (2012). Novi S-pokhidni 1, 2, 4-triazolu, yak potentsiini oryhinalni vitchyzniani veterynarni likarski zasoby [New 1, 2, 4-triazoles S-derivates, as potential original domestic veterinary medications] Farmatsevtychnyi zhurnal, 3, 43-48. [in Ukrainian].

[4] Bilay, I. M., Mihayluk, E. O., Parchenko, V. V., Kaplaushenko, A. G. Panasenko, A. I., \& Knysh, E. G. (2014). Doslidzhennia hepatoprotektornoi aktyvnosti pry eksperymentalnomu hepatyti pid vplyvom pokhidnykh 1,2,4-triazolu [The research of hepatoprotective activity in experimental hepatitis infl uenced by 1,2,4-triazole derivatives] Current issues in pharmacy and medicine: science and practice, 2, 57-59. doi: http://dx.doi.org/10.14739/2409-2932.2014.2.26165. [in Ukrainian].

[5] Belay, I. M., Mikhaylyuk, E. O., Parchenko, V. V., Panasenko, A. I., \& Knysh, E. G. (2014). Vliyaniye 4-amino-5-(furan-2-il)-4H-1,2,4-triazol-3tiola na pokazateli gepatoprotektornoj aktivnosti pri alkogol'nom gepatite $u$ krys [The influence of 4-amino-5-(furan-2-il)-4H-1,2,4-triazole-3-thio on the indices of hepatoprotective activity in alcoholic hepatitis in rats] Vestnik Vitebskogo gosudarstvennogo medicinskogo universiteta, 13(2), 132-137. [in Russian].

[6] Shcherbyna, R. O. (2016). The synthesis and prediction of biological activity in silico for new alkyl derivatives of 4-R-3-(morfolinometylen)-4H-1,2,4-triazole-5-thioles. Ukrainskyi biofarmatsevtychnyi zhurnal, 3, 34-38.

[7] (2017) Kopendium. Lekarstvennye preparaty on-line [Compendium on-line]. Retrieved from http://compendium.com.ua/info/7043/tiotriazolinsup-sup- [in Russian].

[8] Shcherbyna, R. O. (2017). Syntez i fizyko-khimichni vlastyvosti v riadu solei 2-((4-R-3-(morfolinometylen)-4H-1,2,4-triazol-5-il)tio) atsetatnykh kyslot [Synthesis, physical and chemical properties of 2-((4-R-3-(morfolinomethylen)-4H-1,2,4-triazole-5-yl)thio)acetic acid salts]. Current issues in pharmacy and medicine: science and practice, 10(1), 4-8. doi: http://dx.doi.org/10.14739/2409-2932.2017.1.93424. [in Ukrainian].

[9] Stefanov, O. V. (Ed.) (2001) Doklinichni doslidzhenia likarskikh zakhodiv [Preclinic investigation medicines]. Kyiv: Avicena. [in Ukrainian].

\section{Information about authors:}

Shcherbyna R. O., Ph.D., Associate Professor, the Department of Toxicology and Inorganic Chemistry, Zaporizhzhia State Medical University, Ukraine.

Samura T. O., Ph.D., Teaching Assistant, the Department of Clinical Pharmacology, Pharmacy and Pharmacotherapy with the Course of Cosmetology, Zaporizhzhia State Medical University, Ukraine.

Kyrychko B. P., Dr.hab., Professor, Head of the Department of Surgery and Obstetrics, Poltava State Agrarian Academy, Ukraine.

Zvenihorodska T. V., Ph.D., Senior Lecturer, the Department of Surgery and Obstetrics, Poltava State Agrarian Academy, Ukraine.

Hyrenko I. V., Aspirant, the Department of Surgery and Obstetrics, Poltava State Agrarian Academy, Ukraine.

\section{Відомості про авторів:}

Щербина Р. О., канА. фарм. наук, Аоцент каф. токсикологічної та неорганічної хімії, Запорізький державний медичний університет, Україна.

Самура Т. О., канА. меА. наук, асистент каф. клінічної фармакології, фармації і фармакотерапії та косметології, Запорізький Аержавний медичний університет, Україна. Киричко Б. П., А-р вет. наук, професор, зав. каф. хірургії та акушерства, Полтавська державна аграрна академія, україна.

Звенігородська Т. В., канд. вет. наук, старший викиадач каф. хірургії та акушерства, Полтавська Аержавна аграрна академія, Україна.

Гиренко І. В., аспірант каф. хірургії та акушерства, Полтавська Аержавна аграрна академія, Україна.

\section{Сведения об авторах:}

Щербина Р. А., канА. фарм. наук, Аоцент каф. токсикологической и неорганической химии, Запорожский государственный медицинский университет, Украина.

Самура Т. А., канА. меА. наук, ассистент каф. клинической фармакологии, фармации, фармакотерапии и косметологии, Запорожский государственный меАицинский университет, Украина.

Киричко Б. П., А-р вет. наук, профессор, зав. каф. хирургии и акушерства Полтавской государственной аграрной академии, Украина.

Звенигородская Т. В., канА. вет. наук, старший преподаватель каф. хирургии и акушерства, Полтавская государственная аграрная академия, Украина.

Гиренко И. В., аспирант каф. хирургии и акушерства, Полтавская государственная аграрная академия, Украина.

Конфлікт інтересів: відсутній.

Conflicts of Interest: authors have no conflict of interest to declare.

Надійшло Ао редакції / Received: 26.06.2017

Після Аоопрацювання / Revised: 03.07.2017

Прийнято Ао Аруку / Accepted: 28.08.2017 